\title{
ВЛИЯНИЕ РАЗЛИЧНЫХ КОНЦЕНТРАЦИЙ РОЗУВАСТАТИНА НА ЧУВСТВИТЕЛЬНОСТЬ К ЛЕПТИНУ АДИПОЦИТОВ ЭПИКАРДИАЛЬНОЙ И ПОДКОЖНОЙ ЖИРОВОЙ ТКАНИ У БОЛЬНЫХ ИШЕМИЧЕСКОЙ БОЛЕЗНЬЮ СЕРДЦА
}

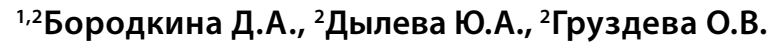

\begin{abstract}
'ГАУЗ КО «Кемеровская областная клиническая больница» имени С.В. Беляева, Кемерово
${ }^{2}$ ФББНУ «Научно-исследовательский институт комплексных проблем сердечно-сосудистых заболеваний», Кемерово
\end{abstract}

ЦЕЛЬ: изучение влияние розувастатина чувствительность к лептину адипоцитов подкожной и эпикардиальной жировой ткани у больных ишемической болезнью сердца.

МАТЕРИАЛЫ И МЕТОДЫ: образЦы Жировой ткани получены при проведении аортокоронарного шунтирования (АКШ) от 84 пациентов с ишемической болезнью сердца (ИБС). Эпикардиальная жировая ткань (ЭЖТ) забиралась из жировых отложений вокруг правых отделов сердца, подкожная (ПЖТ) из подкожной клетчатки нижнего угла средостенной раны. Полученные образцы культивировали в течение 2 суток, с последующим забором супернатанта. Содержание лептина и растворимого рецептора к лептину (LSR) в супернатанте ЭЖТ и ПЖТ определяли иммуноферментным методом с использованием тест-систем фирмы BioVendor (США). Расчет индекса свободного лептина (FLI) определяли по формуле: лептин/ LSR*100). В полученном материале проводилась оценка экспрессия генов лептина (LEP) и его рецептора LSR. Экспрессию генов оценивали с помощью количественной полимеразной цепной реакции (КПЦР) с использованием анализа экспрессии генов TaqManTM (Applied Biosystems, США) в системе ПЦР ViiA 7 (Applied Biosystems, США). С целью изучения влияния розувастатина на чувствительность адипоцитов к лептину проводили культивирование с ним клеточных культур в концентрациях 1 мкмоль/л и 5 мкмоль/л, с последующим определение содержания лептина и LSR в супернатанте и концентрации мРНК их генов. Данные проанализированы с использованием пакета прикладных статистических программ Statistica 9.0.

РЕЗУЛЬТАТЫ: выявлено, что особенности продукции лептина адипоцитами, в большей степени зависит от происхождения клеточной культуры. ЭЖТ характеризовалась более высокой экспрессией гена лептина по сравнению с ПЖТ. Так уровень мРНК гена лептина был в 2,1 раза выше в культуре эпикардиальных адипоцитов по сравнению с подкожными. Не смотря на, это существенной разницы в концентрации самого лептина в супенатанте исследуемых культур найдено не было. Несмотря на то, что интенсивность экспрессии мPHK гена LSR в культуре ЭЖТ была в 2 раза выше, чем в ПЖT, концентрация LSR супернатанте эпикардиальных адипоцитов была на 26\% ниже. Это сопровождалось более высокими значением индекса FLI по сравнению с адипоцитами ПЖТ. Розувастатин в культуре адипоцитов оказывал разнонаправленное влияние на уровень экспрессии гена и секреции растворимого рецептора лептина. Так в концентрации 1 мкмоль/л подавлял экспрессию гена рецептора к лептину и снижал секрецию в культуре адипоцитов ПЖТ. Поскольку розувастатин в концентрациях 1 мкмоль/л приводил к повышению содержания лептина в адипоцитах ПЖТ, что при низком содержании растворимого рецептора к лептину может приводить к развитию лептинорезистентности. В адипоцитах ЭЖТ выявлено увеличение уровня экспрессии гена и секреции растворимого рецептора лептина при введении розувастатина в дозе 5 мкмоль/л Более низкие концентрации розувастатина не оказывали существенного влияния на продукцию рецептора и экспрессию его гена в клеточных культурах ЭЖТ

Выводы: таким образом, установлено, что розувастатин снижают выработку лептина. Однако не всегда это сопровождается регрессией лептинорезистентности

КЛЮЧЕВЫЕ СЛОВА: адипочиты, ишемическая болезнь сердиа, розувастатин, лептин, лептинорезистентость. 